\title{
John Osborne's Luther: An Islamic Interpretation for Boosting Human Fraternity
}

https://doi.org/10.33806/ijaes2000.22.1.3

\author{
Ahmed Shehata \\ Cairo Higher Institute for Languages, Simultaneous Interpretation \\ and Administrative Science, Egypt
}

Received on 17.2.2021

Accepted on 25.7.2021

Published on 1.1.2022

\begin{abstract}
The fictional world John Osborne builds up in Luther (1961) dramatizes Martin Luther's spiritual journey from rooted Catholicism to emerging Protestantism. Throughout the journey, Martin's religious tendency varies according to the belief he adheres to. This paper examines if the aspects of the Christian doctrine Martin is fed with at first and the initiatives he undertakes later on can be reinterpreted through the lens of Islam. The study tries to prove that drama can be used as a platform that enhances religious and multicultural proximity rather than distance between the western world and the Muslim community. It analyzes the Christian tenets in Luther to demonstrate how the religious values embedded in Osborne's representation can be brought close to the principles of the Islamic doctrine. Hence, another endeavour for boosting human fraternity is presented based on picking up a modern English drama that was written sixty years ago and analyzing some of its aspects from an Islamic perspective.
\end{abstract}

Keywords: Christianity, fraternity, Islam, Luther, Osborne

\section{Introduction}

On $21^{\text {st }}$ December 2020, the General Assembly of the United Nations adopted the resolution 75/200 to "proclaim 4 February as the International Day of Human Fraternity, to be observed each year beginning in 2021"1. Commenting on the resolution, the UN Secretary General António Guterres (2020) said, "As we commemorate the International Day of Human Fraternity, let us commit to do more to promote cultural and religious tolerance, understanding and dialogue". This international endeavour comes after His Holiness Pope Francis and Prof. Ahmad Al-Tayyeb, the Grand Imam of Al-Azhar, had signed in Abu Dhabi the 'Document on Human Fraternity for World Peace and Living Together' in 2019. The objective of the document is to safeguard creation and the entire universe. Thanks to these two initiatives and other instances whether adopted by national organizations like the Paris Peace Forum (2017) or by academic scholars such as Ayoob and Lussier (2020). In a further step, this paper uses drama, a main genre of literature, as a platform to examine if it can contribute to the de-escalation of the tension between the East and the West. Once the de-escalation is attained, the chances for boosting human fraternity can be maximized. The paper tries to enhance the Western readers' belief in their proximity to the Islamic culture and the possibility to minimize what Campbell (2019:60) refers to as "violent cultural wars". 
Islam and Christianity are the dominant religions in the East and the West. In the aftermath of the attacks of September $11^{\text {th }}, 2001$, several studies analyzed the relationship between the orient and the occident (Pattberg 2009; Quilter 2016). Because most of these studies were conducted within the Western world, they tended to attack contemporary Muslim communities by associating them with 'feeding terrorism' and 'religious intolerance' among a long list of negative imagery incorporating 'hooliganism'. In parallel, the studies assured that they are not waging war against Islam. They also followed a two-wing strategy of reflecting a fashionable image of the West as the promoter of 'world religion' and the 'safeguard of peace' as well as an unpleasant image of the East as 'violent', 'murderer' and 'blind to multiculturalism'. Samuel Huntington promoted the sounding slogan of 'the clash of civilizations and the remaking of world order'. The historical concept of 'East-West Dichotomy' was also still sounding. Due to the politicization of interest, these thinkers relegated the 'difference' between 'traditions'. They undervalued answering the question: How can civilizations, which are supposed to adopt advanced ways of thinking and higher standards of living - according to the definition of 'civilization'- be dragged to clashes?

Because this paper is concerned with drama, not political science, it tries to bring together an example that existed earlier to the recent negative gapping slogans reshaping the relationship between the East and the West. The study scrutinizes the Catholic and Protestant tenets John Osborne dramatizes in Luther comparatively with their Islamic counterparts. The paper analyzes the themes, motivations, warnings, and attitudes associated with Martin's experience since he joins the Augustinian Order till he ends the play as a contented citizen. It elaborates the dramatic incidents that manifest Martin's rebellion against "the established social and political stance of the society" (Patil 2019: 286). The dramatization of the rebellion enabled Osborne to liberate "modern British drama from the genteel exploration of upper-middle class life and opened the door to English social and political realities that few authors since Shaw had presented on stage" (King, 2011: ix). Luther also represents "a man's rebellion against the world he was born into and his attempt to understand life through a personal relationship with God" (Carter 1969:76). Along 'the play's twelve tableaux' (Graver, 2011:115), analysis is devoted to Osborne's representation of: (1) Martin's proceedings into the Augustinian Order; (2) the preaching included in the tools of Good Works; (3) Martin's talk to the brothers in the convent of the Augustinian Order of Eremites at Erfurt; (4) his talk to Hans Luther; (5)Tetzel's big sale of indulgences; (6) Martin's attempt to challenge what he perceives as evil. First, Martin's religious experience is spotted and his initiatives are highlighted. Second, their contribution to the promotion of peaceful coexistence and tolerance is scrutinized. Third, the meanings of their similar counterparts in Islam are brought closer. The study investigates the compatibility of the dramatized contents in Luther with Islam. It attempts to answer one main question: Is there an affinity between the Christian tenets Osborne dramatizes in Luther and the Islamic precepts based on God's dictated Holy Qur'an and Prophet Muhammad's (صلى الله عليه وسلم) sayings? 


\section{Martin's proceedings into the Augustinian Order}

Osborne's play opens with Martin's being received into the Augustinian Order and the choice he must undertake as the first step to be a monk. The Prior's speech, "Now you must choose one of two ways: either to leave us now, or give up this world, and consecrate and devote yourself entirely to God and our Order" (1.1.13), rationalizes man's freedom of choice, which is an indicator of the freedom of religion. Martin has to choose either to publically renounce worldly interests and dedicate his spiritual life to serving God and the Church or to go back to sensual life and enjoy its lustful pleasures. If Martin's split is represented at an early stage of the play, it does not end with his joining the order. It manifests itself throughout the play. According to Gilliard (1973:68),

From the opening to the final curtain, Martin is faced with the choice between two ways; he must make choices between his doubt and his need to believe as he attempts to alleviate his inner crises: choices between the world and his order, the rule and his conscience, the Church and Germany, the peasants and the princes, celibacy and his sexual urges, the Pope and scripture; and the most compelling choice underlying all others, between belief and unbelief.

Though the Prior's speech foregrounds the concept of 'monasticism' which is not an Islamic principle, it mandates man's decision to go through the religious experience he adheres to or to adopt a secular way of living. In Islam, the freedom of choice is dictated by Allah in The Holy Qur'an. Allah says,

There is no compulsion in religion. Verily, the Right Path has become distinct from the wrong path. Whoever disbelieves in Tâghût $t^{l}$ and believes in Allâh, then he has grasped the most trustworthy handhold that will never break. And Allâh is All-Hearer, All-Knower. (The Qur'an, al-Baqarah [The Cow], 2:256) ${ }^{2}$

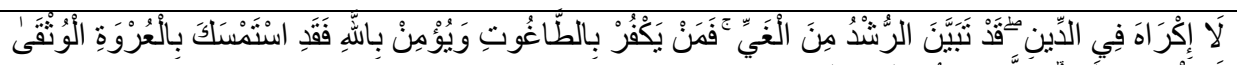

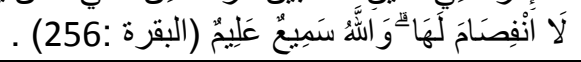

Thus, faith is perceived as an intensely personal issue and consequently man has free will to determine his own path in life. The difference in associating the above English quotation with Islam is that monasticism forbids man's sensual joy, whereas Islam promises Muslims happiness in their lifetime and the hereafter if they live their mortal life on a religious basis (The Qur'an, Al-A'raf [The Heights or the Wall with Elevations], 7: 32).

The notion of 'investment in man' Osborne dramatizes in Luther in 1961 and which turned in 2017 to be an initiative announced by the World Bank Group under the title of The Human Capital Project (World Bank 2018) was introduced by the Islamic culture long ago. The Prior tells Martin, "The Lord divest you of the former man and of all his works. The Lord invest you with the new man" (1.1.13). What the Prior means is that Martin's joining the Order heightens God's investment in him. As the incidents of the play proceed, Martin's other capabilities take a wider 
spectrum of secular fields of knowledge. His philosophy of life can be traced in his talk to Staupitz especially when he explains that "allegories aren't much help in theology - except to decorate a house that's been already built by argument" (2.2.52-53). His use of logic is shown in his argument with Cajetan over the 95 theses against indulgences and the dictatorship of the Church (2.4.68-71). He also challenges the accusations Eck raises against him with an emphasis that even his enemies agree that all his books are 'harmless' and "can be read without damaging the most fragile Christian" (3.1.82). Consequently, the investment in Martin is not only religious. It is multi-dimensional and Martin's expanding awareness is mainly due to his open-mindedness, which is the outcome of God's investment in him. Similarly, Allah explains that He invests in man through teaching him different fields of knowledge. Allay says,

Similarly (to complete My Blessings on you), We have sent among you a Messenger (Muhammad صلى الله عليه وسلم) of your own, reciting to you Our Verses (the Qur'ân) and purifying you, and teaching you the Book (the Qur'ân) and the Hikmah (i.e. Sunnah, Islâmic laws and Fiqhjurisprudence), and teaching you that which you used not to know. (The Qur'an, al-Baqarah [The Cow], 2:151)

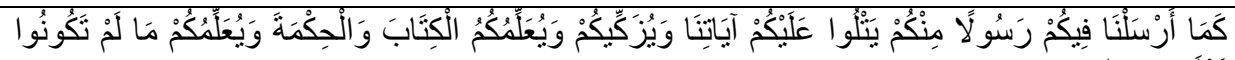

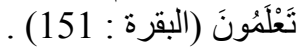

The above verse clarifies that 'recitation' is the method Allah has chosen to 'teach' Muslims what 'purifies' their souls. These teachings include the morals and wisdom recommended in The Holy Qur'an as well as in the Sunnah, which Khalil and Effat (2021: 13) define as "all The Hadiths (Traditions) of Prophet Muhammad (peace be upon him)". The teachings extend to encompass within their scope Islamic Law, Fiqh, which is knowledge of the Self- its rights and responsibilities (Abdur-Rashid, 2019: 1).Thus, both Christian and Islamic feeding sources guarantee Christians' and Muslims' elevation as well as the best practices with one another.

\section{The preaching included in the tools of Good Works}

As a part of Martin's proceedings into the Order, Osborne dramatizes 'some monks' standing at a refectory table. After their prayers, they sit down and eat in silence. While they are eating, one of the Brothers, whom Osborne gives the name of 'Reader', reads from a lectern the tools of Good Works and provides Martin with a long list of principles, instructions and warnings.

The first principle the Reader tells about is "to love Lord God with all one's heart, all one's soul, and all one's strength" (1.1.17). This theme of divine love requires a necessary invitation to place the love of God at the top of a Christian's priorities. It aims at advancing the Christian's spirituality. Comparatively in Islam, Allah says,

And of mankind are some who take (for worship) others besides Allâh as rivals (to Allâh). They love them as they love Allâh. But those who believe, love Allâh more (than anything else). If only, those who do wrong could 
see, when they will see the torment, that all power belongs to Allâh and that Allâh is Severe in punishment. (The Qur'an, al-Baqarah [The Cow], 2:165)

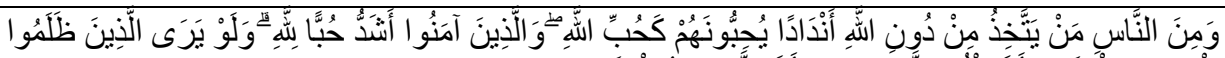

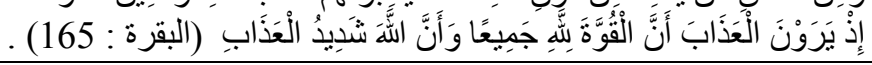

Allah also necessitates that a Muslim's interest in worldly pleasures should come next to his love for Him. Allah instructs Prophet Muhammad (صلى اله عليه وسلم) as He says,

Say: if your fathers, your sons, your brothers, your wives, your kindred, the wealth that you have gained, the commerce in which you fear a decline, and the dwellings in which you delight are dearer to you than Allâh and His Messenger, and striving hard and fighting His Cause, then wait until Allâh brings about His Decision (torment). And Allâh guides not the people who are Al-Fâsiqûn (the rebellious, disobedient to Allâh. (The Qur'an, al-Taubah [The Repentance], 9:24)

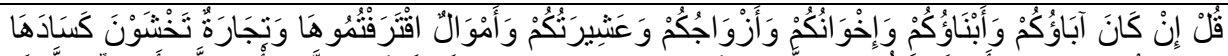

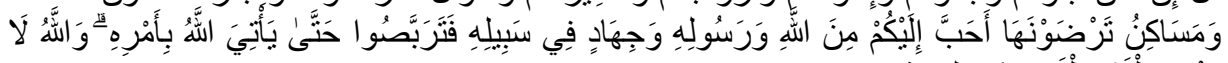

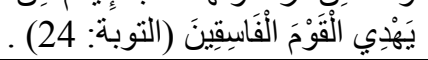

In this verse, Allah clarifies that believers should love Allah and Prophet Muhammad (صلى الله عليه وسلم) more than their: (1) fathers, the direct origin; (2) sons, the offspring; (3) brothers, the dearest relatives; (4) wives, the life companions; (5) kindred, preferable affinities; (6) wealth, the materialistic gain; (7) commerce, the financial interest and the source of living, (8) dwelling, the residence. Consequently, the English and Arabic illustrations show how Christianity and Islam emphasize that loving God with all one's heart is the essence of belief because it is incomparable and transcendental.

Showing benevolence towards neighbours is present in Luther and the Islamic doctrine. The Reader instructs Martin to love "one's neighbour as oneself" (1.1.17). The Christian instruction can be brought closer to Allah's clarification that Muslims should be benevolent towards certain classes of people including two categories of neighbours. Allah says,

Worship Allâh and join none with Him (in worship); and do good to parents, kinsfolk, orphans, Al-Masâkîn (the poor), the neighbour who is near of kin, the neighbour who is a stranger, the companion by your side, the wayfarer (you meet), and those (slaves) whom your right hands possess. Verily, Allâh does not like such as are proud and boastful. (The Qur'an, An-Nisa' [The Women], 4:36)

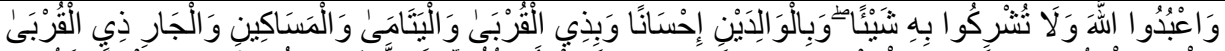

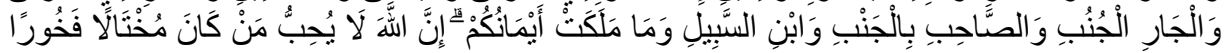
(النساء: 36) 
The prohibition of killing someone for an unjust cause is emphasized, and the legal permission of taking retribution because of killing someone for a just cause is rationalized. In Luther, the Reader reminds Martin not to kill (1.1.17). In Islam, Allah says,

And do not kill anyone whose killing Allâh has forbidden, except for a just cause. And whoever is killed wrongfully (Mazlûman intentionally with hostility and oppression and not by mistake), We have given his heir the authority [to demand Qisâs, - Law of Equality in punishment - or to forgive, or to take Diyah (blood-money)]. But let him not exceed limits in the matter of taking life (i.e. he should not kill except the killer). Verily, he is helped (by the Islâmic law). (The Qur'an, Al-Isra' [The Journey by Night], 17:33)

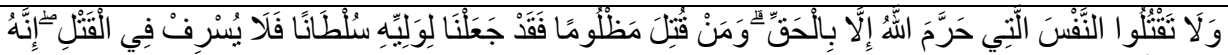

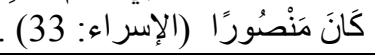

The prohibition of fornication, theft, wrongful desire for what others possess, and bearing false witness are all included in the tools of Good Works. Martin is asked "Not to commit adultery, Not to steal, Not to covet, Not to bear false witness" (1.1.17). The four prohibitions appear vividly in Islam. Allah says, "And come not near to unlawful sex. Verily, it is Fâhishah (i.e. anything that transgresses its limits: a great $\sin$ ), and an evil way (that leads one to Hell unless Allâh forgives him" (The Qur'an, Al-Isra' [The Journey by Night], 17:32).

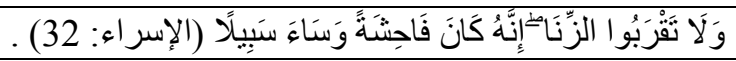

Moreover, the prohibition of theft is not only mentioned but also accompanied by showing the harsh penalties imposed on the accused. Allah says, "And (as for) the male thief and the female thief, cut off (from the wrist joint) their (right) hands as a recompense for that which they committed, a punishment by way of example from Allâh. And Allâh is All-Powerful, All-wise" (The Qur'an, AlMa'idah [The Table Spread with Food], 5:38).

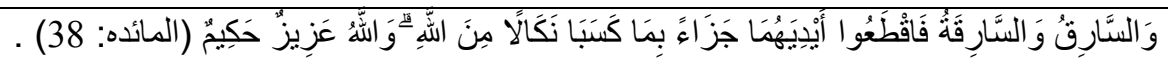

Muslims should abandon yearning to covet too. In The Holy Qur'an, Allah tells the story of His prophet Dawud (David) and the two brothers who own ewes. One of the brothers, who owns one ewe, complains that his brother, who owns 99 ewes, tries to overpower him in speech to hand his only ewe to him. Commenting on the story, Allah explains that "many partners oppress one another, except those who believe and do righteous good deeds, and they are few" (The Qur'an, Sâd [Sâd], 38:24). Thus, seeking the possession of what belongs to others is forbidden even among brothers because it is a form of oppression. 
Not to bear false witness is a characteristic of true Muslims. Allah says, "And those who do not bear witness to falsehood, and if they pass by some evil play or evil talk, they pass by it with dignity" (The Qur'an, Al-Furqan [The Criterion], 25:72).

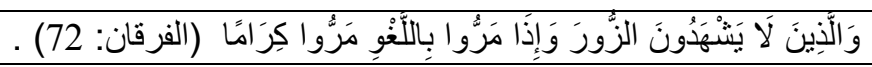

Respecting all human beings can be seen in the Reader's reminding Martin that he should 'honour all men' (1.1.17) as well as in the Qur'anic verse, "And indeed We have honoured the Children of Adam, and We have carried them on land and sea, and have provided them with At-Tayyibât (lawful good things), and have preferred them above many of those whom We have created with a marked preferment" (The Qur'an, Al-Isra' [The Journey by Night], 17:70).

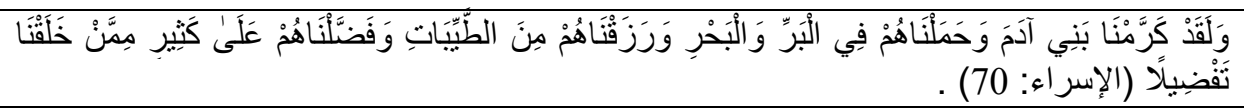

The two illustrations stress the image that man is not only respected but also highly ranked among all God's creations.

Martin is instructed to take the vow that he must 'chastise' the body (1.1.17). The state of keeping a male person away from an illegal sexual discourse is a must in Islam. Sahl bin Sa'd narrated that Allah's Messenger (صلى اله عليه وسلم) said, "Whoever can guarantee (the chastity of) what is between his two jaw-bones and what is between his legs (i.e., his mouth, tongue and his private parts), guarantee Paradise for him" (Al-Hilậli and Khận 1995: 265)³.

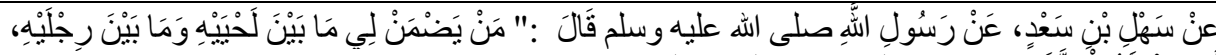

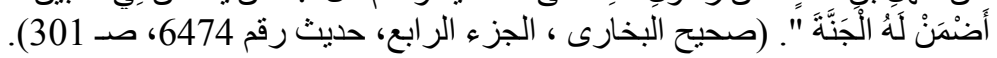

To love fasting is another similar theme between what the Reader says (1.1.17) and numerous Qur'anic verses that favour fasting as a pillar of Islam. For instance, Allah says, "O you who believe! Observing As-Saum (the fasting) is prescribed for you as it was prescribed for those before you, that you may become Al-Muttaqûn (the pious)" (The Qur'an, al-Baqarah [The Cow], 2:183).

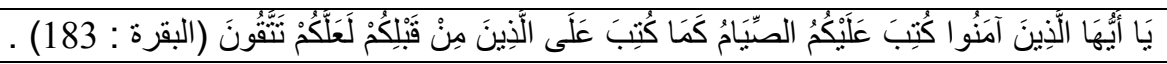

If Allah states that the target of fasting is to enable a Muslim to be pious, further clarification is found in Prophet Muhammad's (صلى الله عليه وسلم) saying, As-Siyâm (the fasting) is Junnah (protection or shield or a screen or a shelter from the Hell-fire). So, the person observing Saum (fasting) should avoid sexual relation with his wife and should not behave foolishly and impudently, and if somebody fights with him or abuses him, he should say to him twice, 'I am fasting'. (Al-Hilậlî and Khận 1995:37) 


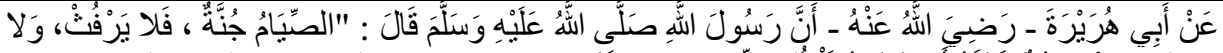

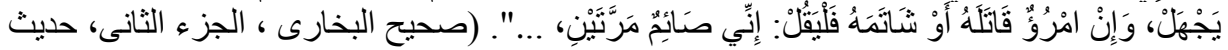

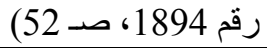

Asceticism is another theme Christianity and Islam advocate. Both religions assert that sticking to luxurious life may spoil the spirituality of the heart. The Reader asks Martin "not to seek soft living” (1.1.17). The metaphor in 'soft living' represents a temptation that a man can hardly resist especially among the numerous hardships of life. In Islam, Prophet Muhammad (صلى الله عليه وسلم) also once advised Mu'az Ibn Jabal, his envoy to Yemen, as he said, "Beware of soft grace as Allah's worshippers cannot be described as enjoying soft grace".

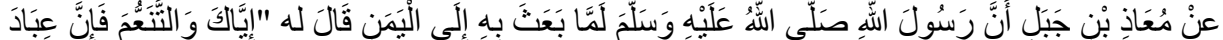

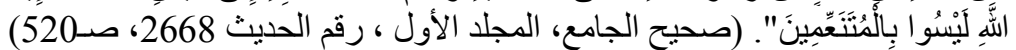

Among the tools of Good Works are asking all Christians to visit the sick, bury the dead, and help the afflicted (1.1.17). In Islam, Abu Hurairah reported that Allah's Messenger ( صلى الله عليه وسلم)said,

A Muslim has six rights he should pay to another Muslim. It was said "what are these rights? O Allah's Messenger!" Thereupon he said: (1) when you meet him, you greet him (with the greeting of Islam); (2) when he invites you to pay him a visit (e.g. to a feast), you accept it; (3) When he asks you for advice or counseling, you give him your recommendations; (4) when he sneezes and thanks Allah (by saying: all praise is due to Allah), you invoke that Allah may bestow His mercy on him (by saying: Yarhamoukom Allah); (5) when he falls ill, you should visit him frequently (to ask about his health and supply him with needs); (6) when he passes away, you should follow his bier (follow his funeral until he is buried).

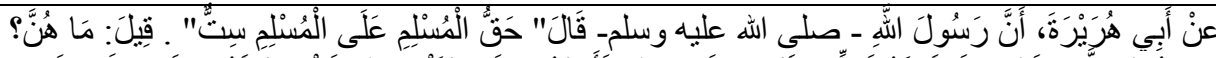

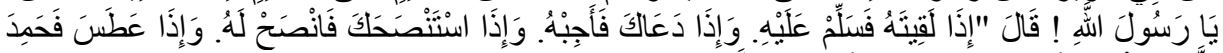

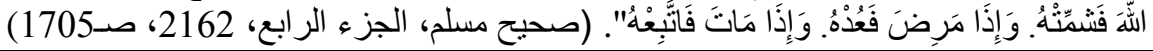

Islam invites Muslims to help the 'afflicted'. The term 'afflicted' refers to miserable persons who are "affected by an impairment of normal physical or mental function" (The Free Dictionary). Afflicted people may also include indebted persons defeated by loans and straitened poverty. Muslim narrated that Abu Qatada (one of the Prophet's companions) heard Allah's Messenger (صلى الله عليه وسلم ) saying, "Whoever is willing to be pleased that Allah may release him from the calamities and hardship of the Resurrection Day, he should release the hardship of an afflicted man in lifetime".

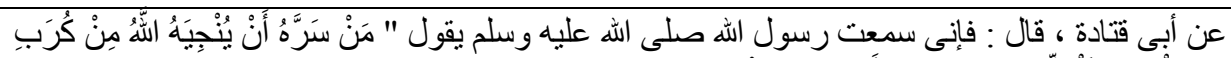

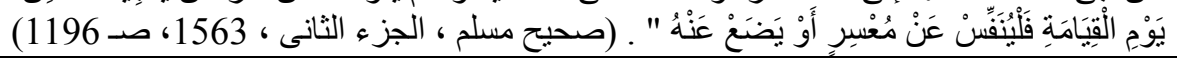


If the Reader uses personification to remind Martin not to yield to anger (1.1.17), all Muslims are reminded not to be controlled by anger either. Allah explains that true believers must avoid greater sins and when they are angry they forgive (The Qur'an, Ash-Shura [The Consultation], 42:37). Their ability to forgive reflects that they are not dominated by the fury of outrage.

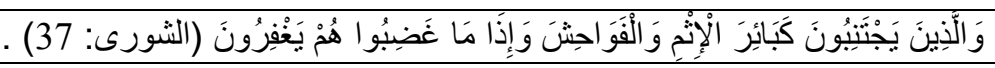

In Luther, Osborne uses metaphors to warn Martin against attaining the two evil traits of 'nursing grudge' and 'holding guile in heart' (1.1.17). Similar warnings appear in the Islamic culture, though their representation is different. In order to explain how 'grudge' is a calamity during man's lifetime, its absence among the members of the 'pious' who will dwell paradise in the Hereafter is described as a privilege that makes tranquility dominant. Allah promises to remove grudge from the breasts of 'the pious' as He says, "And We shall remove from their breasts any deep feeling of bitterness (that they may have). (So they will be like) brothers facing each other on thrones" (The Qur'an, Al-Hijr [The Rocky Tract], 15:47).

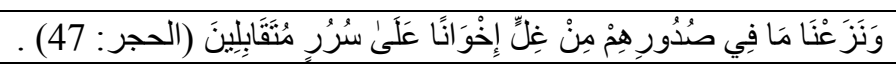

Allah also associates, in a harsh and direct description, 'guile' with wickedness. Allah says, "And thus We have set up in every town great ones of its wicked people to plot therein. But they plot not except against their ownselves, and they perceive (it) not"' (The Qur'an, Al-An'am [The Cattle], 6:123).

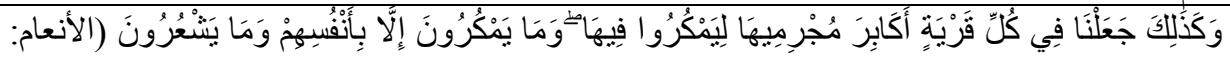

Allah clarifies that cunning and deceit are two evils the wicked people manipulate to plot against society but they are absent-minded as they cannot feel that, in reality, they plot against themselves.

Longing for the Hereafter constitutes another similarity between what Martin is fed with and the Islamic preaching. The Reader asks Martin to "desire eternal life with all [his] spiritual longing" (1.1.18). Similarly, the Islamic perspective of longing can be seen in the Qur'anic verse,

And whoever desires the Hereafter and strives for it, with the necessary effort due for it (i.e. does righteous deeds of Allâh's Obedience) while he is a believer (in the Oneness of Allâh - Islâmic Monotheism) - then such are the ones whose striving shall be appreciated, (thanked and rewarded by Allâh). (The Qur'an, Al-Isra' [The Journey by Night], 17:19)

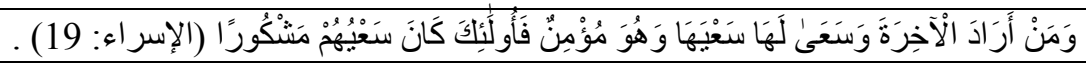


Moreover, the Reader says that should 'keep death daily' before his eyes (1.1.18). In Islam, Abu Hurairah narrated: Prophet Muhammad (صلى اله عليه وسلم) said, "keep mentioning and remembering the most subversive - death".

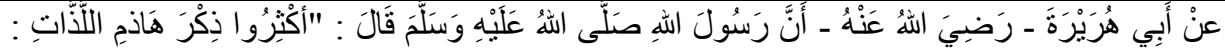

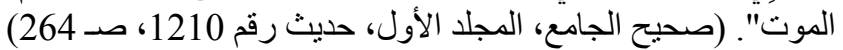

The tools of Good Works necessitate that a Christian should "keep constant vigilance over the actions of [one's] life" (1.1.18). In other words, man should be precautious in all his deeds because God observes him. The same instruction is stated in The Qur'an as Allah tells Muslims that He knows what is in their minds and that they must fear Him (The Qur'an, al-Baqarah [The Cow], 2:235).

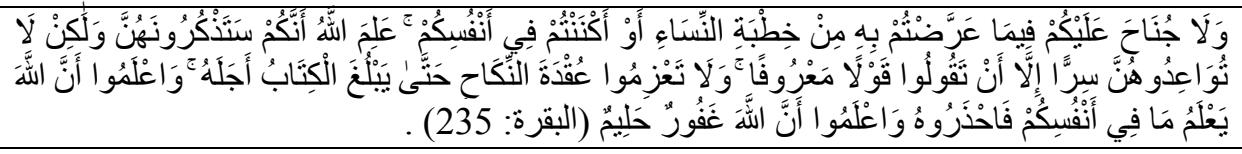

The Reader goes on to remind Martin that he should watch God in all his deeds; he tells him, "To know for certain that God sees you everywhere" (1.1.18). The reminder signifies that a Christian should devote his actions in life to God and that his belief in God makes him sure that God watches him all the time. This relationship between God and man is positioned in an advanced stage in Islam, the stage of perfection. The concept is present in Abu Hurairah's narration that one day while Prophet Muhammad ( صلى اله عليه وسلم) was sitting in the company of some people, the angel Jibrael (Gabriel) came to him and asked him about the difference among faith, Islam and ihsan (perfection). The third part of the Prophet's reply explained that ihsan means "to worship Allâh عز و جل as if you see Him, and if you cannot achieve this state of devotion then you must consider that He is looking at you" (Al-Hilậlî and Khận, 1995:84).

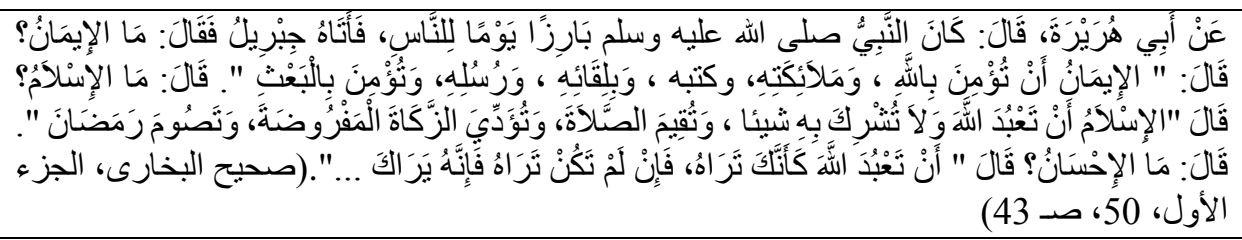

Warning against evil and vain talk is dramatized in Luther as Martin is asked to keep his mouth from 'evil and depraved talk'. He should not 'love much speaking'. He should not 'speak vain words' (1.1.18). In Islam, Allah elaborates that one of the characteristics of true believers is, "And those who turn away from Al-Laghw (dirty, false, evil vain talk, falsehood, and all that Allâh has forbidden)" (The Qur'an, Al-Mu'minun [The Believers], 23:3).

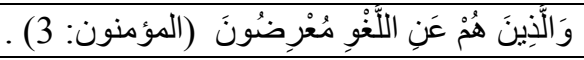


Man's spirituality reaches higher spheres when he listens to holy readings. In this sense, it is logical that Martin is reminded to "listen gladly to holy readings" (1.1.18). The use of the adverb 'gladly' conveys willingness and preparedness. Allah says, "So, when the Qur'ân is recited, listen to it, and be silent that you may receive mercy" (The Qur'an, Al-A'raf [The Heights or the Wall with Elevations], 7: 204).

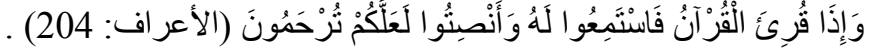

The use of the verb 'listen' instead of 'hear' or any other auditory verb reflects willingness too, especially if it is accompanied by an invitation to silence.

The Reader invites Martin to apply himself 'frequently to prayer' and to be 'daily in prayer, with tears and sighs' to confess his sins to God (1.1.18). The invitation shows the double function of prayer. It is placed among the top rituals of Christianity. It is the means for a Christian to repent his past sins and consequently, to be redeemed. Prayer is also a pillar of Islam. Allah necessitates that a Muslim prays five times a day. Allah says, "Guard strictly (five obligatory) As-Salawât (the prayers) especially the middle Salât (i.e. the best payer- 'Asr). And stand before Allâh with obedience [and do not speak to others during Sâlat (prayers)]" (The Qur'an, al-Baqarah [The Cow], 2:238).

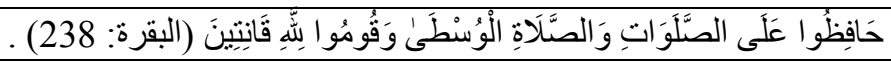

The reward God promises true believers in the Hereafter is represented in a certain sequence in Luther. The Reader tells Martin,

Behold, these are the tools of the spiritual craft. If we employ these unceasingly day and night, and render account of them on the Day of Judgment, then we shall receive from the Lord in return that reward that $\mathrm{He}$ himself has promised: Eye hath not seen nor ear heard what God hath prepared for those that love him (1.1.18).

Similarly, Abu Hurairah narrated that Allah's Messenger (صلى الله عليه وسلم) said. "Allah said: I prepared for my good worshippers what eye has not seen, what ear has not heard, and what human being's heart has never perceived".

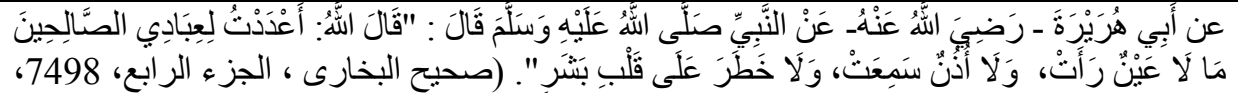

\section{Martin's talk to the brothers in the convent of the Augustinian Order}

Warning that the first wanton look may lead to the violation of religious rules is represented in Luther. In Act One, there is a conversation between Martin and two brothers in the convent of the Augustinian Order. One of the brothers reminds the other brother and Martin that "it is not only by touch and by being affectionate that 
a man excites disorderly affection in a woman" (1.1.21). He determines that "a wanton eye is a wanton heart" (1.1.21). This association between a man's excitement in a woman after looking at her is comparable to another association in Islam. Allah instructs Prophet Muhammad (صلى اله عليه وسلم) to teach Muslims that a male Muslim who believes in God should not intentionally glance at a nonmahram (marriageable) woman because his first look may lead him to desire her. This kind of sight that excites in man his desire for sexual discourse is forbidden. Allah says, "Tell the believing men to lower their gaze (from looking at forbidden things), and protect their private parts (from illegal sexual acts). That is purer for them. Verily, Allâh is All-Aware of what they do" (The Qur'an, An-Nur [The Light], 24:30). Thus, in both cases, a man is instructed not to look at a woman desirably.

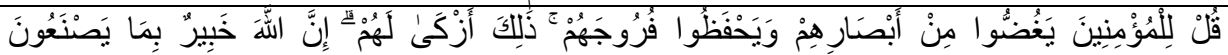

$$
\begin{aligned}
& \text { (النور: 30) }
\end{aligned}
$$

The same conversation sheds light on Martin's psychological dilemma. Martin is not satisfied that his heart is content. Coincidently, he is sure that God sees his 'murmuring heart' (1.1.22). He believes there are mistakes within the practices of the Catholic monks but his state of contentment is not acceptable to him. He is anxious because his heart is once associated with contentment and once with 'murmuring'. The disharmony between what Martin feels and what he actually performs can be brought close to a similar perspective in Islam. At the end of a long verse in The Qur'an, Allah says, “...Allâh might test what is in your breasts; and to purify that which was in your heart (sins), and Allâh is All-Knower of what is in (your) breasts" (The Qur'an, Al-'Imran [The Family of Imran], 3:154).

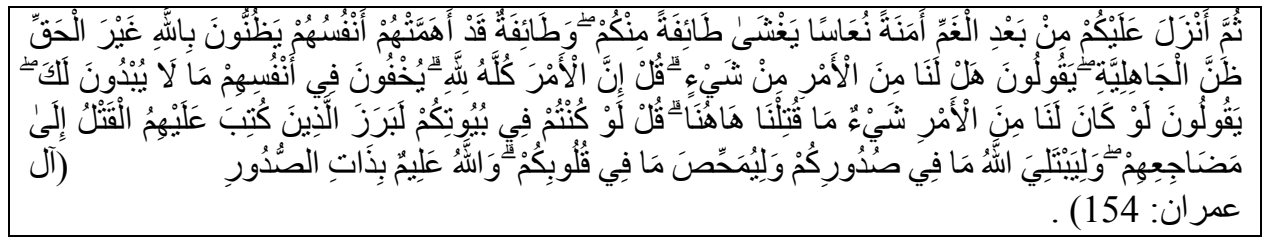

Thus, Allah compares the state of inner conflict within a man to an examination of the man's trial of himself. After the trial, the man should make up his mind to choose his own path in life. If the man chooses to obey God properly, he is rewarded with the purification of his heart.

While talking to Brother Weinand, Martin raises an important question, "What is the use of all this talk of penitence if I can't feel it" (1.2.26). For Martin, penitence is a sense that touches his heart. In other words, Martin's heart is the sensor that detects his feeling of God's acceptability of his penitence. Repentance as the work of the heart is evident in Prophet Muhammad's ( صلى الله عليه وسلم) saying, as reported by Abu Hurairah, 
intervention of the Catholic Church in his relationship with God and, consequently, he is excommunicated. What Martin tries to achieve is a cornerstone of the Islamic dogma. The existence of any Islamic establishment should not spoil a Muslim's direct contact with Allah especially among the majority Sunnis. Allah says, "And indeed We have created man, and We know what his ownself whispers to him. And We are nearer to him than his jugular vein (by Our knowledge) (The Qur'an, Qaf, $50: 16)$.

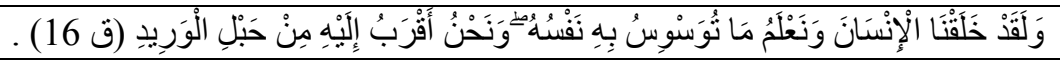

\section{Tetzel's big sale of indulgences}

Osborne dramatizes Tetzel's big sale of indulgences in the marketplace in Jotebög to amusingly criticize the secular business of the Catholic Church. The scene witnesses Tetzel's manipulation of the Pope's title to achieve a certain materialistic goal as he tries to motivate the mob to buy indulgences. The result is "the sound of coins clattering like rain into a great coffer" (2.1.51). The accumulation of coins can be associated with Pope Leo X's prestigious appearance (2.5.75), and Emperor Charles V's luxurious entrance (3.1.81). Thus, the representatives of the spiritual and the temporal authority enjoy a pattern of life based on benefiting from Tetzel's sale. The whole scenario leads to Martin's disputation of the indulgences. A similar criticism is traced in The Qur'an as Allah warns Muslims against the manipulation of one another and accumulation of money illegally and giving this money to rulers. Allah says, "And eat up not one another's property unjustly (in any illegal way e.g. stealing, robbing, deceiving, etc), nor give bribery to the rulers (judges before presenting your cases) that you may knowingly eat up a part of the property of others sinfully" (The Qur'an, al-Baqarah [The Cow], 2:188).

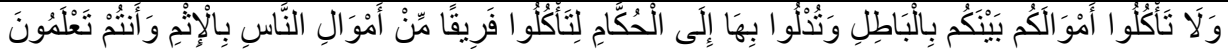

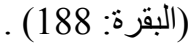

Martin's denunciation of selling indulgences is expressed openly at the Diet of Worms. He dares to argue both the representatives of the Church and the State. His angry argument with Cajetan and debate with Von Eck can be reinterpreted as 'saying a word of truth before an unjust ruler'. The same tendency is in Islam as Prophet Muhammad (صلى اله عليه وسلم) said that one of the greatest means of jihad (holy fighting) is "a word of truth (or justice) spoken before a tyrant ruler".

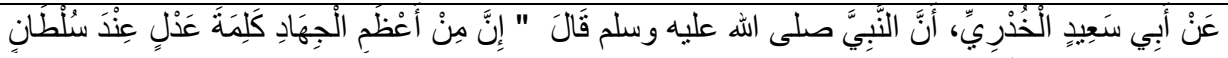

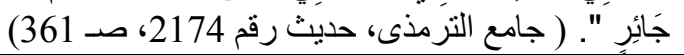

\section{Martin's attempt to challenge what he perceives as evil}

John Osborne is known for his "excoriating prose and intense critical stance towards established social and political norms" (Wathore, 2018:28). His 
contemporary literature "took the form of social revolt in which the writer dealt with the individual in his society and his conflict with the church, the government, the family and the community" (Ajjawi, 1975:7). Dramatically, Martin is characterized by similar qualities. He dares to uncover the vicious practices of the Church and the State. First, he decides to 'write down' his 95 theses against indulgences and the practices of the Roman Catholic Church and to "nail' the theses to the door of the Castle Church. The two verbs 'write down' and 'nail' are verbs of action performed by hand. Second, Martin 'argues' with Cajetan, the papal legate, and 'debates' with Von Eck, secretary to the archbishop of Trier. The verbs 'argue' and 'debate' are other verbs of action performed by 'tongue'. Third, Martin ends his public life and enjoys his private life once he feels that his word is heard. The last decision is one of the heart and mind. Martin's attitude can be justified on the ground that he is "less interested in actions than in minds" (Gilleman, 2002 :91). The sequence of changing evil through the action of the hand, the tongue, and the heart can be linked to a similar sequence in Islam. Abu Sa'id al-Khudri reported: the Messenger of Allah said, "Whoever amongst you sees an evil, he must change it with his hand; if he is unable to do so, then with his tongue; and if he is yet unable to do so, then with his heart; and this is the weakest form of faith" (Islamweb 2017).

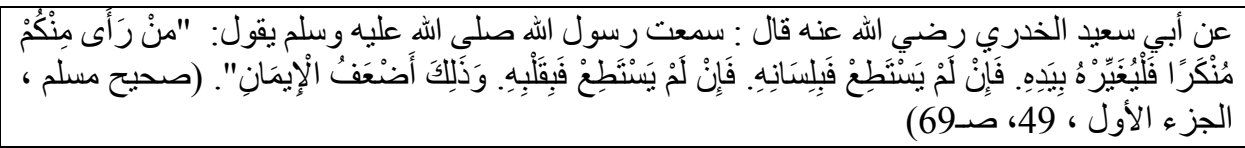

Martin is portrayed as sensitive to his social responsibility. His established scholarship as a Doctor of Theology has brought him open-mindedness. He finds himself in no position to stand silent and helpless amidst some practices of the Church and the State which his heart and mind refuse. In other words, he finds himself split between what Joseph Barbara (1972: 108) describes as "micro-social and macro-social aspects". So, Martin's agony is a logical consequence of the disharmony between what goes around him and what he believes in. Martin's dilemma can be brought close to a similar state Allah tells about in The Holy Qur'an. Though the Islamic context is different, it signifies the necessity that man should feel harmony among all his deeds. Allah says, "Allâh has not made for any man two hearts inside his body...." (The Qur'an, Al-Ahzâb [The Confederates], 33:4). If man had got two hearts, he should have been able to cope with contradictory feelings. But because this is impossible, his heart should be satisfied with his reciprocal interaction with his environment.

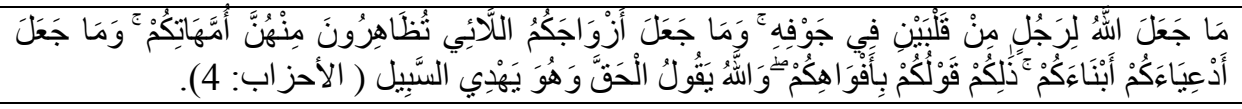

Martin's seeking reform is characterized by his 'condemnation of violence'. In Act Three, Scene Two, Osborne dramatizes the consequences of the Peasants' Revolt. The scene can be subdivided into three parts: stage direction, the Knight's 
monologue, and the Knight's dialogue with Martin. The whole image created by the stage direction is one of chaos and bloodshed. Osborne represents the auditory image of 'the sounds of cannon and shouts of mutilated men'. The visual imagery of the men is intensified by the appearance of 'the bloody bulk of a peasant's corpse' on the stage. The physical and psychological state of the Knight is described as 'fatigued, despondent', 'stained and dirty'. The Knight's monologue includes comparing Martin's scalp to 'blotchy and itchy' skin and his body to 'a millstone' to touch. He says that he was able to 'smell' every inch of Martin even from where he was standing in the Diet of Worms. Additionally, the monologue is full of verbs of violence like burst, pluck, holler for blood, cut up, and hang up. The knight uses nouns like spark, gunpowder, war, slaughter house, blood, and fire (3.2.86-87). Thus, the overall image is one of disorder.

Martin's dialogue with the Knight signifies his tendency to peaceful reform. He denies the existence of 'an orderly revolution'. He emphasizes that 'Christians are born to suffer, not fight'. He associates his seeing 'chaos' with his seeing 'the devil's organ' (3.2.89). Martin's denial of the Peasants' Revolt has a religious basis. He explains that he expects God to keep his word. He asks the Knight, "If your peasants rebelled against that Word, that was worse than murder because it laid the whole country waste, and who knows now what God will make of us Germans!" (3.2.91). He argues that the peasants 'kicked against authority' and 'plundered and bargained' in God's name. Consequently, Martin believes that changing prevailing evil should not come at the price of pushing the whole country into danger. $\mathrm{He}$ advocates that people should be tolerant of the corrupt practices of rulers rather than rising against them and dismantling their homelands. The effectiveness of Martin's tendency is highlighted in view of the chaotic conditions revealed by the stage direction and the Knight's words.

From an Islamic perspective, seeking reform should involve neither rising against authority nor contributing, in one way or another, to bringing a country to the brink of an abyss. Allah forbids that Muslims should disobey their rulers as $\mathrm{He}$ says,

O you who believe! Obey Allâh and obey the Messenger (Muhammad صلى (اله عليه وسلم), and those of you (Muslims) who are in authority. (And) if you differ in anything amongst yourselves, refer it to Allâh and His Messenger (صلى الله عليه وسلم ), if you believe in Allâh and in the Last Day. That is better and more suitable for final determination. (The Qur'an, An-Nisa' [The Women], 4:59)

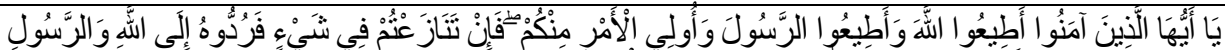

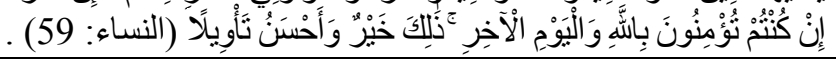

In this verse, Allah organizes the relationship between the ruler and the ruled. Allah ranks the Muslims' obedience to their rulers third after their obedience to Him and His Messenger. Allah points out that in case Muslims are not satisfied with their authority, they should be guided by Allah's and the Messenger's words. This guidance is a condition that proves Muslims' belief. The scenario is described as 
'better' because it nips strife in the bud, and consequently the chances for emerging violence are minimized.

\title{
Conclusion
}

Rereading Luther through the lens of Islam proves that there is an affinity between the Christian tenets Osborne dramatizes based on rooted Catholicism and emerging Protestantism, on the one hand, and the Islamic precepts based on God's dictated Holy Qur'an and Prophet Muhammad's ( صلى الله عليه وسلم) sayings, on the other. This affinity can promisingly advocate the western educated reader who is interested in English literature and lacks confidence in the tolerance of Islam to modify his attitude towards the Muslim world based on using drama as a platform to illustrate the proximity of the represented Christian values and the Islamic culture. Such proximity is traced through a number of analyses that show shared advocacies and warnings. Thematically, free choice is perceived as the basis for initiating new spiritual tendencies. Faith is treated as a personal issue. There is an emphasis that man's love for God must rank first. The concept of 'investment in man' is similarly introduced with its spiritual and secular sides. There are numerous shared invitations to love one's neighbor, honor all men, love fasting, visit the sick, bury the dead, help the afflicted, long for the hereafter, keep death daily before one's eyes, keep vigilance over one's actions, watch God in all one's deeds, listen to holy readings, perform prayers, believe in God's everlasting mercy, and feel repentance. The Christian culture in Luther and the Islamic culture share the prohibition of adultery, murdering someone for an unjust cause, stealing, bearing false witness, evil and vain talk. Both cultures also warn against yearning to covet, enjoying soft living, yielding to anger, nursing grudge, holding guile in heart, and having wanton eyes. They motivate true believers to follow God's path as they remind them of God's rewards in the hereafter. They criticize the manipulation of the mob for the sake of the ruling authority and they show that challenging prevailing evil can be achieved through the work of the hand, the tongue, and the heart. Disobedience of rulers is forbidden even if the rulers are not good because seeking reform should not be violent as this may be at the price of endangering homelands.

\author{
Ahmed Shehata \\ Cairo Higher Institute for Languages, Simultaneous Interpretation and \\ Administrative Science, Egypt \\ ORCID Number: 0000-0002-2068-7896 \\ Email: ashehata1978@gmail.com
}




\section{Endnote:}

${ }^{1}$ The term refers to anything worshiped other than God. It includes false deities like stone, sun, stars, angels ...etc.

${ }^{2}$ All verses of The Holy Qur'an are cited as follows: The Qur'an (in italics), followed by a comma, the title of the Surah (chapter), the translation of the title into English between two square brackets, the number of the chapter, colon, the number of the verse(s). This pattern appears more accurate especially for non-Muslim readers so that they can easily trace the cited verse(s).

${ }^{3}$ The translation of the meaning of the Hadith into English is typically copied from the footnotes included in the version of the translation of the meaning of the Noble Qur'an into English. The cited version includes the translation of the meaning of The Qur'an in the body of the book, whereas the translation of the meaning of the Hadith is given in the form of footnotes.

\section{References}

Abdur-Rashid, Khalil. (2019). 'Islamic Law (Fiqh)'. Cambridge: Harvard University.https://scholar.harvard.edu/files/khalilabdurrashid/files/harvard _islamic_law_seminar_2019-2020.pdf. (Retrieved on 25 April 2021).

Ajjawi, Mahmoud Ahmed. (1975). Social Criticism in John Osborne's Plays. M.A. Thesis Unpublished, the American University of Beirut, Beirut, Lebanon.

Al-Hilậlî, Muhammad Taqî-ud-Dîn and Muhammad Muhsin Khận. 1417 (Hijri) [1995]. Translation of the Noble Qur'an in the English language. Madina, K.S.A: King Fahd Complex for the Printing of the Holy Qur'an.

Ayoob, Mohamed and Danielle N. Lussier. (2020). The Many faces of political Islam: Religion and politics in Muslim societies. $2^{\text {nd }}$ ed. Michigan: University of Michigan Press.

Barbara, Joseph. (1972). The shades of anger: an examination of four protagonists in the plays of John Osborne within the context of anger. M.A. Thesis published or unpublished, University of Ottawa, Canada.

Campbell, Charles. (2019). 'The captivity narrative and east-west understanding in Aboulela's The kindness of enemies'. International Journal of ArabicEnglish Studies, 19 (1): 53-70.

Carter, Alan. (1969). John Osborne. Edinburgh: Oliver \& Boyd.

Gilleman, Luc. (2002). John Osborne: Vituperative Artists. New York: Routledge.

Gilliard, Bari Lynn. (1973). Lessons in feeling: an analysis of four plays by John Osborne. M.A. Thesis published or unpublished?, University of Montana, USA.

Graver, David. (2011). 'Luther: the morbid grandeur of corporeal history'. In Patricia D. Denison (ed.), John Osborne: A Casebook, 115-126. New York and London: Routledge. 
Guterres, António. (2020). International Day of Human Fraternity. www.un.org/en/observances/human-fraternity/messages. (Retrieved on 1 February 2021).

Islamweb. (2017). https://www.islamweb.net/en/article/164707/enjoining-goodand-forbidding-evil. (Retrieved on 27 April 2021).

Khalil, Samir Fawzi and Salah Eddin Khalil Effat. (2021). Islamic selections. Book Two. Cairo: Central Department for Books, Libraries, Instruments and Labs, Al-Azhar Al Sharif.

King, Kimball. (2011). 'General editor's note'. In Patricia D. Denison (Ed.). John Osborne: A Casebook. Page numbers New York: Routledge.

Osborne, John. (1961). Luther. London and Boston: Faber and Faber.

Paris Peace Forum. (2017). 'about the Paris peace forum'. https://parispeaceforum.org/faq/\#about. (Retrieved on 23 April 2021).

Pattberg, Thorsten. (2009). The East-west dichotomy: Behold the law of difference. $1^{\text {st }}$ ed. New York: LoD Press.

Patil, B. Y. (2019). 'John Osborne's play Luther: A new discourse in existentialism'. International Journal of English Language, Literature in Humanities, 7 (2): 285-294.

Pope Francis and Ahmad Al-Tayyeb. (2019) 'A document on human fraternity for world peace and living together'. Vatican: Libreria Editrice Vaticana. http://www.vatican.va/content/francesco/en/travels/2019/outside/documets/ papa francesco_20190204_documento-fratellanza-umana.html. (Retrieved on 10 June 2020).

Quilter, John G. (2016). 'The nature of religious dialogue, the diversity argument and religious pluralism'. In Jānis Tālivaldis Ozoliņš (Ed.), Religion and Culture in Dialogue: East and West Perspectives, 59-76. Switzerland: Springer International Publishing.

The Free Dictionary. www.thefreedictionary.com. (Retrieved on 25 April 2021).

The Modern Language Association of America. (2009). MLA handbook for writers of research papers. $7^{\text {th }}$ ed. New York: the Modern Language Association of America.

The United Nations. (2020). Resolution adopted by the General Assembly on 21 December 2020. New York: The United Nations, General Assembly (2020). https://undocs.org/en/A/75/L.52. (Retrieved on 1 February 2021).

Wathore, Sunil N. (2018). 'John Osborne: the man behind the artist'. Journal of Research in Humanities and Social Science, 6 (10): 28-33.

World Bank. (2018). The human capital project. Washington DC: World Bank. https://openknowledge.worldbank.org/handle/10986/30498 License: CC BY 3.0 IGO. (Retrieved on 15 December 2020).

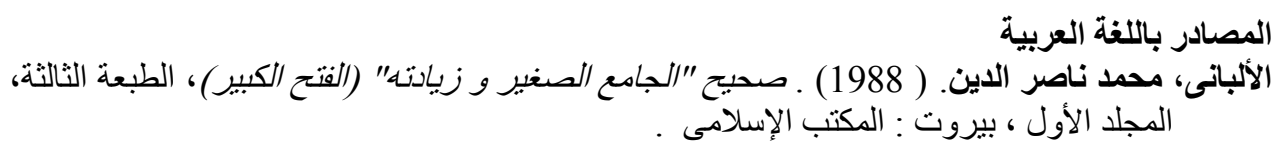


الترمذى، أبى عيسى محمد بن عيسى بن سورة.(1999). جامع الترمذى، الرياض: بيت الافكار الدولية للنشر و التوزيع.

الأهبى ، مصطقى ـ (2000) ـ صحيح البخارى، الجزء الأول، القاهرة : دار الحديث.

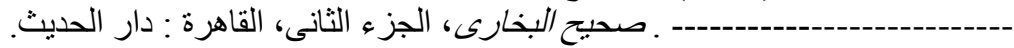
صحبح البخارى، الجزء الجزء الرابع، القاهرة الفاهرة : دار الحديث.

النيسابورى، أبى الحسين مسلم بن الحجاج القشيرى. (1991). صحيح مسلم ، الطبعة الأولى، الجزء الأل الأول ،القاهرة: دار الحديث. 